\title{
Storage of guavas cv. Pedro Sato coated with low molecular weight chitosans
}

\author{
Armazenamento de goiabas cv. Pedro Sato revestidas \\ com quitosanas de baixo peso molecular
}

\author{
Rodrigo Martins Fráguas ${ }^{1 *}$, Tamara Rezende Marques ${ }^{2}$, Enio Nazaré de Oliveira Junior ${ }^{3}$, Denise Alvarenga \\ Rocha $^{2}$, Camila dos Santos Oliveira ${ }^{3}$, Celeste Maria Pato Abreu²
}

${ }^{1}$ Faculdade Marechal Rondon (FMR), Departamento de Química, Vilhena/RO - Brasil

¿Universidade Federal de Lavras (UFLA), Departamento de Química, Lavras/MG - Brasil

${ }^{3}$ Universidade Federal de São João Del-Rey (UFSJ), Departamento de Química, Biotecnologia e Engenharia de Bioprocessos, Ouro Branco/MG - Brasil

\section{*Corresponding Author}

Rodrigo Martins Fráguas, Faculdade Marechal Rondon (FMR), Departamento de Química, Av. Mal. Rondon, 10058, Setor Industrial, CEP: 76980-000, Vilhena/RO - Brasil, e-mail: rodrigofraguas1@hotmail.com

Cite as: Storage of guavas cv. Pedro Sato coated with low molecular weight chitosans. Braz. J. Food Technol., v. 21, e2017112, 2018.

Received: Aug. 08, 2017; Accepted: June 21, 2018

\section{Abstract}

Guava is a highly perishable fruit due to its rapid metabolism during maturation, suffering a loss of firmness a few days after harvesting, which prevents its storage for long periods. Thus there is great interest in the development of new types of packaging that extend its useful life, providing desirable sensory and nutritional characteristics. This study investigated the softening of "Pedro Sato" guavas subjected to treatment with chitosan films of different molecular weights $(132,228$ and $245 \mathrm{kDa})$, at concentrations of $0.5 \%$ and $1.5 \%$. Thus the loss of mass, firmness, pectin content and activities of the hydrolytic enzymes pectin methylesterase and $\beta$-D-glucosidase were evaluated for eight days of storage at room temperature. The results showed that the product treated with chitosan $245 \mathrm{kDa}$ at a concentration of $1.5 \%$ showed lower weight loss and loss of soluble pectin content, as well as greater firmness and total pectin content, as compared to the other treatments. The treatment with chitosan $245 \mathrm{kDa}$ at a concentration of $0.5 \%$ resulted in lower activities of the hydrolytic enzymes analyzed. When compared with the control, the treatments with chitosan at different concentrations were effective in maintaining the postharvest quality of guavas, extending their life by eight days.

Keywords: Psidium guajava L.; Storage; Pectin; Hydrolytic enzymes; Films; Conservation.

\section{Resumo}

A goiaba é uma fruta altamente perecível devido ao seu rápido metabolismo durante a maturação. A fruta sofre perda de firmeza alguns dias após a colheita, o que impede seu armazenamento por longos períodos. Assim, há um grande interesse no desenvolvimento de novos tipos de embalagens que prolonguem sua vida útil, propiciando características sensoriais e nutricionais desejáveis. Este estudo investigou o amolecimento das goiabas cv. Pedro Sato tratadas com filmes de quitosana de diferentes pesos moleculares (132, 228 e $245 \mathrm{kDa}$ ), em concentrações de 0,5\% e 1,5\%. Assim, a perda de massa, a firmeza, o conteúdo de pectinas e as atividades das enzimas hidrolíticas pectina metilesterase e $\beta$-D-glucosidase foram avaliados durante oito dias de armazenamento, à temperatura ambiente. Os resultados mostraram que as goiabas tratadas com quitosana $245 \mathrm{kDa}$, na concentração de 1,5\%, apresentaram menor perda de peso e teor de pectina solúvel, bem como maior firmeza e conteúdo da pectina total, em comparação com os outros tratamentos. O tratamento com quitosana $245 \mathrm{k} \mathrm{Da}$, na concentração de $0,5 \%$, resultou em atividades menores das enzimas hidrolíticas analisadas. Os tratamentos com quitosana em diferentes concentrações foram eficazes na manutenção da qualidade pós-colheita de goiabas quando comparados com o controle, estendendo sua vida útil por oito dias.

Palavras-chave: Psidium guajava L.; Armazenamento; Pectinas; Enzimas hidrolíticas; Filmes; Conservação. 


\section{Introduction}

The postharvest period begins after separation of the fruit from the plant and ends when it is consumed. However, one of the great challenges for Brazilian fruit farming is the preservation of fruit quality after harvest, prolonging the life.

Fruit ripening is accompanied by a number of physical and biochemical processes that results in the synthesis and degradation of pigments, conversion of starch to sugar, firmness loss and the production of volatile compounds. Tissue softening is a major ripening signal, associated with changes in fruit structure and metabolism (LINHARES et al., 2007). Some fruits, including guava, become senescent quickly in the post-harvest period, preventing their storage for long periods.

Brazil is the world's largest producer of red guava, with a production of 345.3 thousand tons in 2014 (JANUÁRIAVIEIRA et al., 2014), the cultivars Paluma and Pedro Sato being amongst the most cultivated varieties in the country. Guava is a highly perishable climacteric fruit, due to its rapid metabolism during ripening and senescence. This phenomenon limits the period of transport and storage, making it difficult or even impossible to send the guava fruit to more distant consumer centres, due to the irreversible losses that occur during transport (XISTO et al., 2004). Most of the production is intended for the domestic market, however major European centres are currently discovering guava and the market is expanding, mainly for table guava (OLIVEIRA et al., 2006; JANUÁRIAVIEIRA et al., 2014). The expansion of the consumer market for fresh guava is conditional to fruit quality and increasing the shelf life, thus various coating methods that modify the surrounding air within the fruit, reducing the levels of $\mathrm{O}_{2}$ and increasing the $\mathrm{CO}_{2}$ levels are being studied to extend the shelf life of guava (BOTELHO et al., 2016; CHITARRA; CHITARRA, 2005; PEREIRA et al., 2003).

For many years, packages were developed with the single purpose of food protection, without presenting any interaction with the food. However, currently there is great interest in developing new types of packaging, such as active ones, which intentionally interact with the food, extending its useful life or giving desirable sensory and/or nutritional characteristics (FORATO et al., 2015). The use of natural products for the development of biodegradable packaging is of great interest to the food industry and society, since it benefits the food and the environment.

The use of edible coatings which, when applied to food, form a barrier that attenuates gas exchange and further improves the appearance, structural integrity and mechanical properties of the foods, is noteworthy (RIBEIRO et al., 2005). Chitosan, which is an amino-polysaccharide obtained from the deacetylation of chitin, is such a coating. It is an animal fibre, biodegradable and non-toxic
(GUERRA-SÁNCHEZ et al., 2009), considered to be one of the most abundant natural polymers in living organisms, such as crustaceans, insects and fungi. When used as a coating, chitosan interferes directly in the growth of pathogens and activates various defence responses in plant tissues, thus helping in the control of the onset of postharvest diseases (GUERRA-SÁNCHEZ et al., 2009; AGRAWAL et al., 2002).

The ripening of guava is a complex process, related to the pectic composition of the cell wall, and changes and degradation of the cell wall components caused by hydrolytic enzymes such as pectin methylesterase (PME) (LINHARES et al., 2007). Knowledge of the changes occurring during these processes is important to clarify and establish the scientific basis that enables the development of new postharvest conservation technologies, thus increasing the useful life of the fruit (ABREU et al., 2012a). Given the above, the present study aimed to determine the effect of edible chitosan coatings on the quality maintenance of guava cv. Pedro Sato for eight days of storage at room temperature.

\section{Materials and methods}

\subsection{Preparation of chitosan solutions with different molecular weights}

Chitosan samples (trade name Chitoclear ${ }^{\circledR}$ ) with different molar weights $(132,228$ and $245 \mathrm{kDa}$ ) were kindly provided by Primex ehf, Iceland, in three different batches: 3493, 3529 and 3142. These three commercial samples of chitosan were characterized (FRÁGUAS et al., 2015) and used in the preparation of solutions, coded respectively as A, B, C, D, E and F, according to Table 1.

The procedure described by Yoshida et al. (2008) was followed in the preparation of the chitosan solutions. The samples were dissolved in 1\% acetic acid solutions with concentrations of $0.5 \%$ and $1.5 \%$, and then homogenized on a magnetic stirrer (Fisatom 711) at room temperature

Table 1. Chemical characteristics and concentrations of the chitosans used in the preparation of the coatings for the groups studied in the experiment.

\begin{tabular}{lccc} 
Group & $\begin{array}{c}\text { Coating/ } \\
\text { concentration }\end{array}$ & $\begin{array}{c}\text { Molar } \\
\text { Weight } \\
\text { Mw (kDa) }\end{array}$ & $\begin{array}{c}\text { Viscosity } \\
\text { (mPa s) }\end{array}$ \\
\hline Control & No coating & Xx & Xx \\
Group A & Chitosan 3493/ 0.5\% & $132 \pm 1.0$ & 5 \\
Group B & Chitosan 3493/1.5\% & & \\
Group C & Chitosan 3529/0.5\% & $228 \pm 9.0$ & 520 \\
Group D & Chitosan 3529/1.5\% & & \\
Group E & Chitosan 3142/0.5\% & $245 \pm 2.0$ & 1,300 \\
Group F & Chitosan 3142/1.5\% & \\
\hline
\end{tabular}

*Information provided by the manufacturer (Primex ehf). 
for 24 hours until complete dissolution. They were then filtered under vacuum using an $11 \mu \mathrm{m}$ filter.

\subsection{Preparation of guavas}

Guavas (Psidium guajava L.) cv. Pedro Sato (350 fruits) were manually picked early in the morning at the half-mature ripening stage (light green coloration) in a commercial orchard located in the municipal district of Lavras, Minas Gerais, altitude $845 \mathrm{~m}$, latitude 21.15 $\mathrm{S}$ and longitude $45.22^{\circ} \mathrm{W}$. They were placed in previously sterilized polyethylene boxes and transported to the Biochemistry Laboratory of the Chemistry Department of the Federal University of Lavras - MG, Brazil.

The fruits were selected based on size, colour and the absence of physiological and mechanical injuries, washed with tap water and separated into 7 groups of 9 fruits each for the treatments. All fruits were immersed in a $0.1 \%$ sodium hypochlorite solution at room temperature for 5 minutes for disinfection. After drying, the fruits were numbered and treated with the different chitosan solutions by immersion for 10 seconds. They were then placed to dry in backrests, secured by the peduncle. Table 1 shows the concentrations of the solutions prepared and the viscosities and molecular weights of the chitosan samples used.

After the coating had dried, the fruits were placed on a steel shelf in the laboratory and kept for a period of eight days at a temperature of $27^{\circ} \mathrm{C} \pm 1^{\circ} \mathrm{C}$ and relative humidity $(\mathrm{RH})$ of $53 \% \pm 1 \%$.

The samples were analysed on the day of harvest and every other day up to the end of the storage period (day 8), taking nine fruits of each treatment for analysis on each treatment day. The endocarps were removed and the pulp chopped into pieces of approximately $1 \mathrm{~cm}^{3}$ to facilitate homogenization. The pieces were manually homogenized, stored in plastic pots and placed in a freezer $\left(-20^{\circ} \mathrm{C}\right)$ for subsequent analysis.

\subsection{Physical analyses}

\section{a) Firmness}

Firmness was assessed using a digital stand penetrometer (TR Turoni, Digital fruit firmness tester 53205, Italy). The tests were carried out in the equatorial position on opposite sides of each fruit, employing an $8 \mathrm{~mm}$ cylindrical probe to a depth of $1 \mathrm{~cm}$. The Digital fruit firmness tester 53205 features ranges up to $20 \mathrm{~kg}$, and the results were expressed in Newton (N).

\section{b) Weight loss}

The fruits were weighed on a Plus OHAUS scale and the loss of fresh weight during storage determined according to the equation $M(\%)=\left[\left(M_{0}-M n\right) / M_{0}\right] \times 100$, where $M$ is the \% loss of fresh fruit weight, $M_{0}$ the mass at zero time (day 0) of storage and $\mathrm{Mn}$ the mass on subsequent days of analysis $(n=8)$.

\subsection{Chemical and biochemical analyses}

a) Insoluble pectin and soluble pectin

Insoluble and soluble pectin were extracted according to the technique standardized by McCready and McCoomb (1952) and quantified using the carbazole reaction, according to Bitter and Muir (1962). The results were expressed in $\mathrm{g}$ galacturonic acid.100 $\mathrm{g}^{-1}$ pulp.

\section{b) Activity of pectin methylesterase}

The activity of pectin methylesterase (PME) was determined according to the technique described by Jen and Robinson (1984). A 1\% citrus pectin solution in $0.2 \mathrm{~N} \mathrm{NaCl}, \mathrm{pH}=7.0$, was used as the substrate at room temperature. The demethylation rate of the pectin added to the enzyme extract was measured by titration of the reaction mixture with $0.01 \mathrm{~N} \mathrm{NaOH}$, maintaining the $\mathrm{pH}$ at 7.0 for 10 minutes. One unit of enzyme activity (EAU) was defined as the ability of the enzyme to catalyse demethylation of the pectin corresponding to one micromol $\mathrm{NaOH}$ per minute under the assay conditions. The results were expressed as $\mathrm{U} \mathrm{g}^{-1}$ fresh weight (EAU).

\section{c) Activity of $\beta$-D-glucosidase}

The $\beta$-D-glucosidase was extracted and quantified according to Linhares et al. (2007), using $0.01 \mathrm{~mol} \mathrm{~L}^{-1}$ p-nitrophenyl- $\beta$-D-glucopyranoside ( $p N P \beta G$ ) as the substrate in a $0.1 \mathrm{~mol} \mathrm{~L}^{-1}$ phosphate-citrate buffer at pH 5.5. The $\beta$-D-glucosidase activity was expressed as milliunits $(\mathrm{mU})$, which correspond to the formation of one nanomol of $p$-nitrophenol per minute under the assay conditions.

\subsection{Experimental design}

A factorial $(7 \times 5)$ completely randomized design (CRD) was used with seven treatments (groups control, $A$, $B, C, D, E$ and F) and 5 storage times (day 0, 2, 4, 6, and 8). The experimental portion consisted of 3 fruits with 3 replications for each treatment. The results were submitted to the variance analysis using the software SISVAR (version 4.6, build 61), and the differences between the means detected using the Tukey multiple comparison test at 5\% probability. When significant, the data were subjected to a regression analysis at $5 \%$ probability. The data were processed using the originPro 8.0 software, version 8.0724 (B724).

\section{Results and discussion}

The coating applied to the guavas was transparent and invisible to the naked eye after evaporation of the solvent, as also reported by Forato et al. (2015). The use of edible films on fruit surfaces is a technique aimed at 
increasing the shelf life of the fruits, acting as an adjuvant, reducing, but not replacing, the use of an inedible synthetic packaging.

The weight loss (Figure 1A) increased during eight days of storage at room temperature $\left(22.6^{\circ} \mathrm{C}\right.$ and $\left.\pm 75 \% \mathrm{RH}\right)$, with the highest values being observed in the control fruits. The fruits treated by immersion in different chitosan solutions, especially at a concentration of $1.5 \%$, showed lower weight losses during storage as compared to the control.

The chitosan causing the lowest weight loss of the coated fruits was the $245 \mathrm{kDa}$ one. At the end of storage (Table 2) fruits covered with this material at concentrations
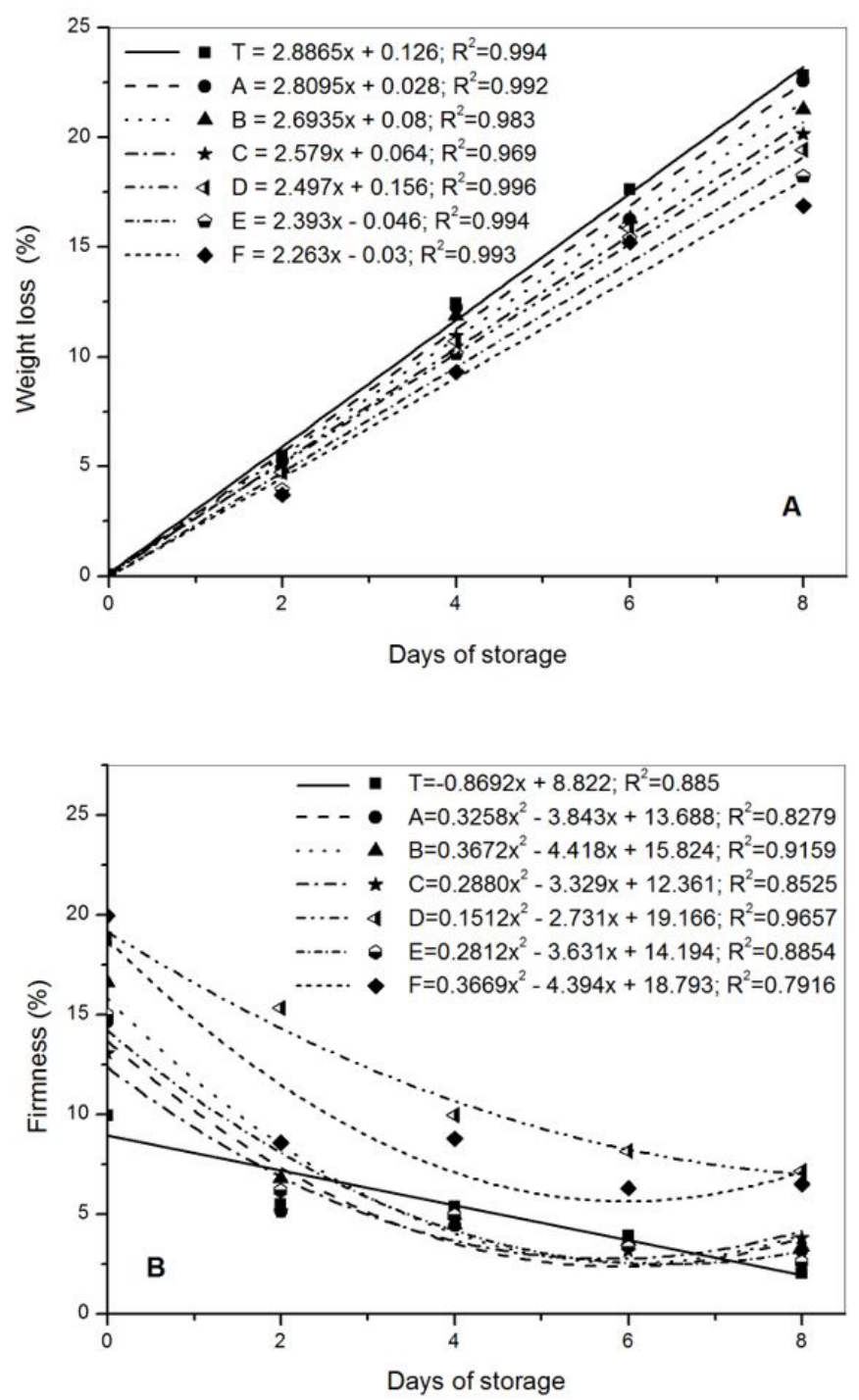

Figure 1. The effects of weight loss (A) and firmness (B) in 'Pedro Sato' guavas, coated and not coated with chitosans, during 8 days of storage. Groups: T (No coating); A (0.5\% Chitosan $132 \mathrm{kDa}) ; \mathrm{B}(1.5 \%$ Chitosan $132 \mathrm{kDa}) ; \mathrm{C}(0.5 \%$ Chitosan $228 \mathrm{kDa})$; D (1.5\% Chitosan $228 \mathrm{kDa})$; E (0.5\% Chitosan $245 \mathrm{kDa})$; and $F(1.5 \%$ Chitosan $245 \mathrm{kDa})$. The data were subjected to a regression analysis $(p<0.05)$. of $0.5 \%$ and $1.5 \%$ showed weight losses of $16.22 \%$ and $17.47 \%$, respectively, less than that of the control (T) $(22.73 \%)$. Fruits treated with chitosan $228 \mathrm{kDa}$ and chitosan $132 \mathrm{kDa}$ at concentrations of $0.5 \%$ and $1.5 \%$ showed weight losses between $18.77 \%$ and $22.60 \%$. The values for weight of the control $(T)$ and treatment $(A)$ showed no significant differences at $p \leq 0.05$, but there were significant differences in weight loss for the treatments of B to F. For all treatments, the percent losses observed were lower than those reported for guavas suitable for consumption (MANICA et al., 2000).

The data for weight loss shown in Figure 1 were showed a linear fit and the slope of the curve was physically interpreted in the equation as the rate of weight loss per day of storage (\%/day). The fastest rate of weight loss during storage was observed for the control (T) (2.89\%/day), whereas the fruits treated with chitosan $132 \mathrm{kDa}$ at concentrations of $0.5 \%(A)$ and $1.5 \%(B)$ showed weight loss rates of 2.81 and $2.69 \% /$ day, respectively. The weight loss rates of fruits coated with chitosan $228 \mathrm{kDa}$ (intermediate molar weight) were $2.58 \%$ /day at the concentration of $0.5 \%(C)$ and $2.50 \% /$ day at the concentration of $1.5 \%$ (D). The lowest weight loss rates were observed for the fruits coated with chitosan $245 \mathrm{kDa}$ at concentrations of $0.5 \%$ (E) (2.39\%/day) and $1.5 \%(F)(2.26 \% / d a y)$. The greater reduction in weight loss rate of the control fruits as compared to those coated with chitosan can be explained by the filmogenic and barrier properties of the chitosan. Yoshida et al. (2008) reported that chitosan films of different molar weights had different water vapour transmission rates, tensile strengths and elongations at break.

Regarding fruit firmness, it was observed that the coatings with chitosan $228 \mathrm{kDa}(\mathrm{D})$ and $245 \mathrm{kDa}(\mathrm{F})$, mainly at the concentration of $1.5 \%$, contributed to maintenance of the fruit pulp firmness, with values of $7.60 \mathrm{~N}$ and $7.50 \mathrm{~N}$, respectively, as compared to $2.53 \mathrm{~N}$ for the control (Figure $1 \mathrm{~B}$ and Table 2), thus corroborating with the results for mass loss (Figure 1A).

Table 2. Average values for weight loss (\%), firmness (N), insoluble pectin (\%) and soluble pectin (\%) at the end of storage ( $8^{\text {th }}$ day).

\begin{tabular}{ccccc} 
Treatment & $\begin{array}{c}\text { Weight } \\
\text { loss } \\
(\mathbf{\%})\end{array}$ & $\begin{array}{c}\text { Firmness } \\
\mathbf{( N )}\end{array}$ & $\begin{array}{c}\text { Insoluble } \\
\text { pectin } \\
\mathbf{( \% )}\end{array}$ & $\begin{array}{c}\text { Soluble } \\
\text { pectin } \\
\mathbf{( \% )}\end{array}$ \\
\hline $\mathrm{T}$ & $22.73 \mathrm{a}$ & $2.53 \mathrm{a}$ & $2.20 \mathrm{a}$ & $0.63 \mathrm{a}$ \\
$\mathrm{A}$ & $22.60 \mathrm{a}$ & $3.70 \mathrm{~b}$ & $2.16 \mathrm{~b}$ & $0.61 \mathrm{~b}$ \\
$\mathrm{~B}$ & $21.25 \mathrm{~b}$ & $3.72 \mathrm{~b}$ & $2.11 \mathrm{~b}$ & $0.59 \mathrm{c}$ \\
$\mathrm{C}$ & $19.39 \mathrm{c}$ & $4.40 \mathrm{c}$ & $2.15 \mathrm{~b}$ & $0.61 \mathrm{~b}$ \\
$\mathrm{D}$ & $18.77 \mathrm{~d}$ & $7.60 \mathrm{~d}$ & $2.15 \mathrm{~b}$ & $0.55 \mathrm{~d}$ \\
$\mathrm{E}$ & $17.47 \mathrm{e}$ & $3.10 \mathrm{e}$ & $2.12 \mathrm{~b}$ & $0.60 \mathrm{~b}$ \\
$\mathrm{~F}$ & $16.22 \mathrm{f}$ & $7.50 \mathrm{~d}$ & $2.05 \mathrm{c}$ & $0.55 \mathrm{~d}$ \\
\hline
\end{tabular}

Means followed by the same letter do not differ statistically according to Tukey's test $(p \leq 0.05)$. 
The loss of firmness is one of the most important changes occurring in guava during the ripening process (PINTO et al., 2010). All treatments were efficient in decreasing this and showed greater firmness at the end of storage when compared to the control group. The behaviour of the fruits coated with chitosan $245 \mathrm{kDa}$ may be associated with the fact that its greater viscosity produces "sticky" solutions, facilitating adhesion of the material to the external surface of the fruit. The reduction in firmness during ripening has been attributed to chemical modifications and degradation of cell wall components (PINTO et al., 2010; VILAS BOAS et al., 2013), as well as to the decrease in integrity of the fruit (CHITARRA; CHITARRA, 2005). The less firm the fruit, the more susceptible it is to attack by microorganisms; besides becoming less resistant to impact.

Linhares et al. (2007) analysed the mass loss of 'Pedro Sato' guavas after 25 days of refrigeration, and found that the mass loss for the control fruits was $21.80 \%$; whereas for fruits treated with calcium chloride it was $21.13 \%$ and for fruits treated with 1 -MCP it was $18.60 \%$.

Cerqueira et al. (2011) stored 'Kumagai' guavas for eight days at a temperature of $22{ }^{\circ} \mathrm{C} \pm 2{ }^{\circ} \mathrm{C}$ and $70 \% \pm 5 \%$ $\mathrm{RH}$ coated with $6 \%$ chitosan, and showed they had a lower mass loss of $5.67 \%$ on the eighth day, when compared with other chitosan concentrations, other treatments and the control, which showed a loss of $8.00 \%$ on the eighth day. The treatment with $6 \%$ chitosan interfered with the normal loss of firmness, probably due to the excessive restriction of gas exchange between the plant tissue and the external environment. This resulted in a change in metabolism, causing a reduction in the cell wall degradation processes and pectin breakage, thus maintaining greater tissue firmness.

Most weight loss presented by the fruits not coated with chitosan film was probably due to water loss resulting from the transpiration rates, while smaller losses by the coated fruits can be explained by mitigation of the water loss to the external environment due to the coating, reaching equilibrium in the micro environment with a change in atmosphere. At the end of storage, the group treated with chitosan $245 \mathrm{kDa}$ showed an excellent aspect, whereas the fruits that received no type of treatment were inappropriate for consumption, at an advanced stage of senescence (Figure 2).

The total pectins or insoluble pectins are important for the postharvest conservation of fruits (VILAS BOAS et al., 2013), since they are structural components of the cell wall and middle lamella and influence their texture. During storage an increase in the average insoluble pectin contents from $1.63 \%$ (day 0 ) to $2.20 \%$ was observed for all treatments (Figure 3A). This may have been related to extractability of the pectin and to water loss during storage for all treatments, resulting in a higher pectin concentration. At the beginning of storage, pectinase has little access to the pectin (substrate) located near

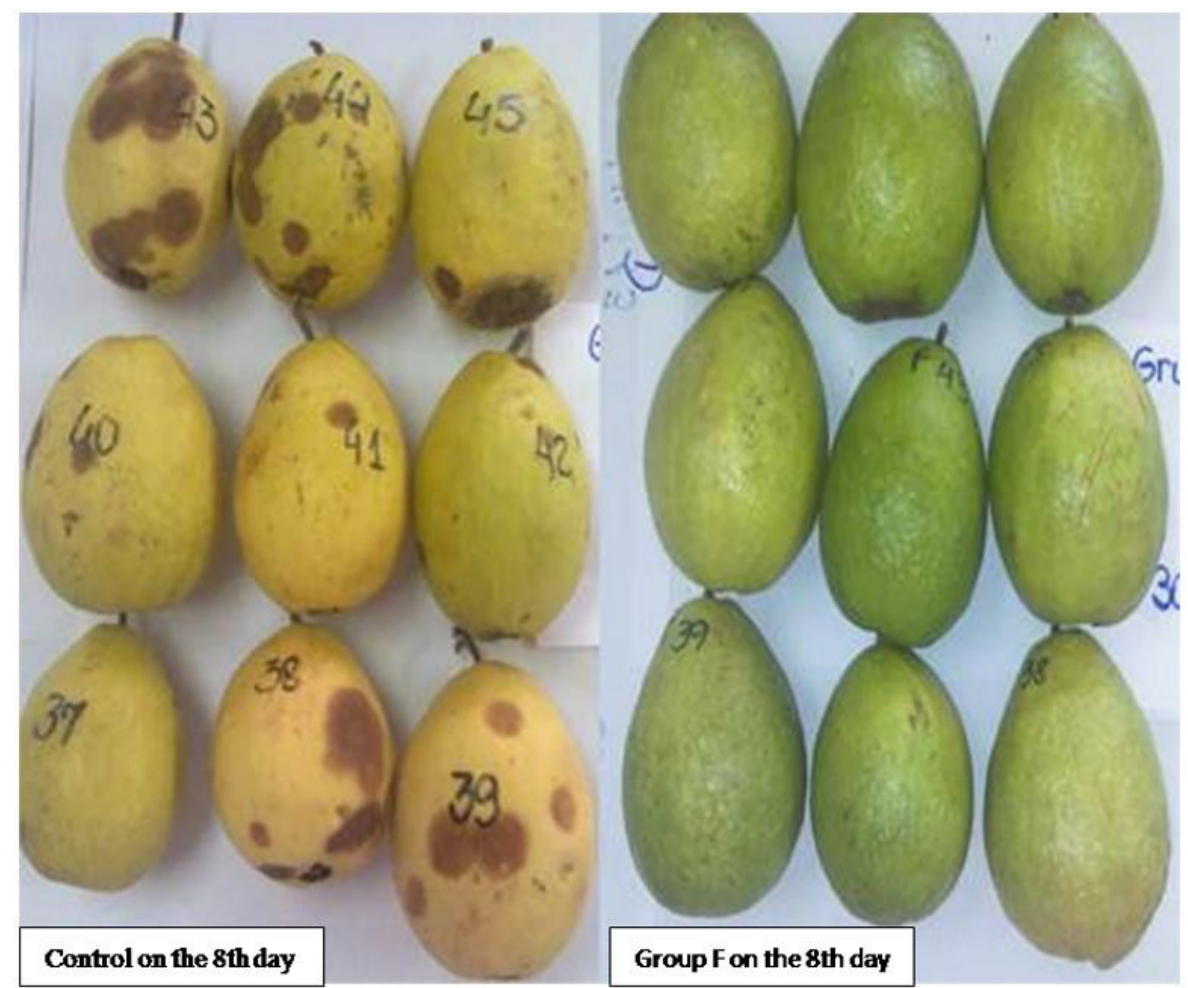

Figure 2. Appearance of the control group (no coating) and group $F(0.5 \%$ Chitosan $245 \mathrm{kDa})$ at the end of storage. 

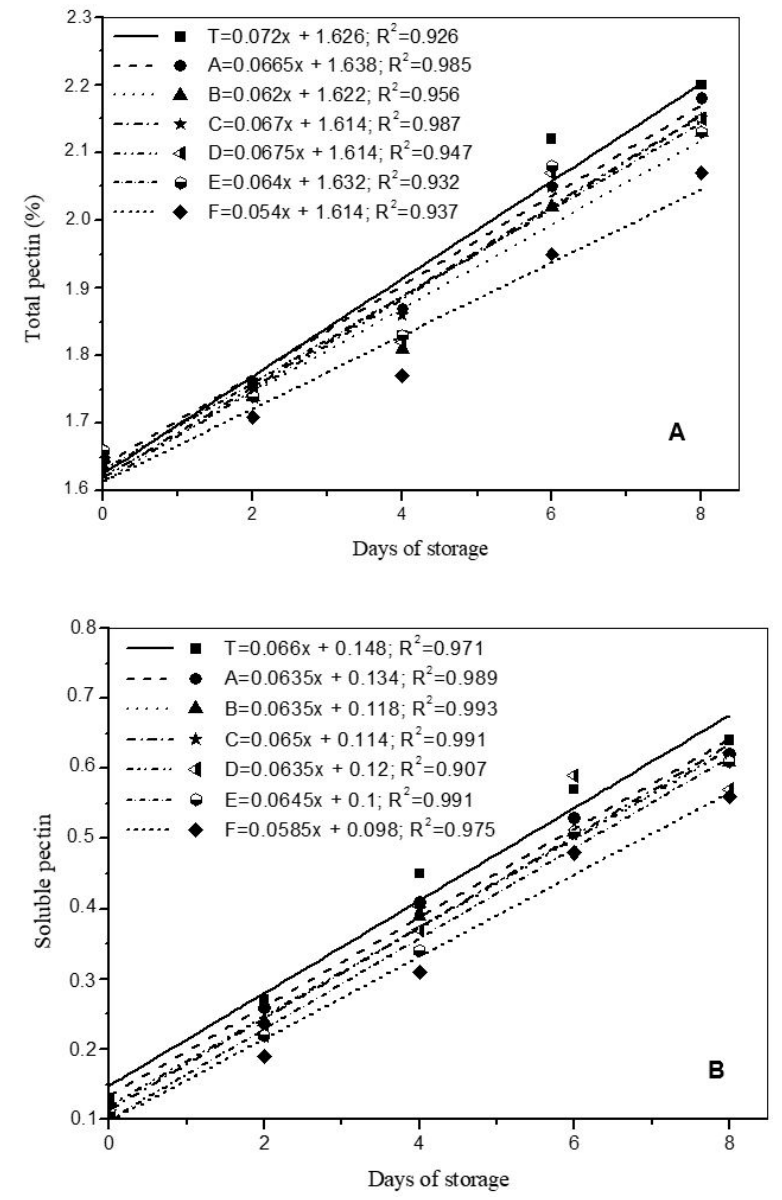

Figure 3. The contents (\%) of insoluble pectin (A) and soluble pectin (B) in 'Pedro Sato' guavas coated and not coated with the different chitosans during 8 days of storage. Groups: T (No coating); A $(0.5 \%$ Chitosan $132 \mathrm{kDa})$; B (1.5\% Chitosan $132 \mathrm{kDa})$; C $(0.5 \%$ Chitosan $228 \mathrm{kDa}) ; \mathrm{D}(1.5 \%$ Chitosan $228 \mathrm{kDa})$; E $(0.5 \%$ Chitosan $245 \mathrm{kDa})$; and $\mathrm{F}(1.5 \%$ Chitosan $245 \mathrm{kDa})$. The data were subjected to a regression analysis $(p<0.05)$.

the cell wall, preventing its complete extraction. With time the extraction yield increases, since part of the cell wall polysaccharides undergoes hydrolysis with the advancement of ripening, facilitating the enzymatic degradation of the pectin (OLIVEIRA JUNIOR et al., 2004).

At the beginning of storage it was observed that the fruits had similar contents of insoluble pectin of $1.63 \%$, but at the end of storage (day 8 ), the fruits with smaller weight losses (coated with chitosan $245 \mathrm{kDa}$ ) also presented the lowest insoluble pectin contents (2.05\%) compared with those of the control (2.20\%), the values showed a significant difference at $p \leq 0.05$ (Table 2). The contents of insoluble pectin found on treatment $F$ at the end of storage (day 8 ) was of $2.05 \%$ (Figure $3 \mathrm{~A}$ ) and of $0.55 \%$ for soluble pectin (Figure $3 \mathrm{~B}$ ) giving a total of pectin $2.60 \%$ which is similar to the average value found in the literature for guavas of about 2.5\% (ABREU et al., 2012b; LINHARES et al., 2007).
Figure 3B shows an increase in the soluble pectin contents of the control fruits throughout ripening from $0.13 \%$ (day 0 ) to $0.63 \%$ (day 8 ), which is usually accompanied by a decrease in protopectin, which occurred for all treatments. Linhares et al. (2007) also observed an increase in the soluble pectin contents from $0.26 \%$ to $0.54 \%$ in 'Pedro Sato' guavas treated with calcium. This was due to the action of proteolytic enzymes that degraded the protopectins, transforming them into soluble pectins, causing softening of the fruits. The fruits coated with chitosan $245 \mathrm{kDa}(\mathrm{F})$ and $228 \mathrm{kDa}(\mathrm{D})$ at a concentration of $1.5 \%$ were those that showed lower soluble pectin contents $(0.55 \%)$ at the end of storage, when compared to the fruits of other treatments $(0.57$ to $0.6 \%)$, and were also the ones that were firmer on the eighth day of storage (Figure 1B), unlike the fruits that received no coating, which were the least firm and showed the highest soluble pectin contents at the end of storage, indicating a higher metabolic rate in relation to the coated fruits. Coating decreased gas exchange with the environment by slowing the ripening process, with the subsequent maintenance of fruit quality.

The degradation of the pectic substances is associated with softening of the fruits (LIU et al., 2009), as well as the depolymerisation and dissolution of polysaccharides, water loss and degradation of other compounds during the chemical modifications of the cell wall (CHEN et al., 2011).

Various chemical transformations, primarily related to the carbohydrate, organic acid and pectin contents, occur during fruit ripening and are commonly associated with the action of specific enzymes, such as: pectin methylesterase (PME) and polygalacturonase (PG), enzymes capable of degrading the pectic substances found in the cell wall and middle lamella of the parenchyma cells of various fruits and vegetables. PME activity is related to fruit softening, and since their principal substrate is the methoxyl group of pectins, hydrolysis of these compounds occurs (CHITARRA; CHITARRA, 2005). However, the activity of $P G$ is not observed in guava, or may be very low (ABREU et al., 2012a; LINHARES et al., 2007), making the information on the activity of these enzymes contradictory, and the mechanisms that control ripening not clearly defined.

The peak PME activity (460.8 $\mathrm{mU} \mathrm{g}^{-1}$ fresh weight) was observed on the fourth day of storage in the control group (Figure 4A) and from this point on it decreased, indicating that the substrate of this enzyme (methylated pectins) had already been reduced and that the enzymes that degrade the middle of the pectin chain were already active.

An increase in the PME activity was also observed in the other treatments, but with a lower intensity as compared to the fruits of the control group, indicating lower activity of this enzyme in fruits coated with $1.5 \%$ chitosan $228 \mathrm{kDa}$ (320.0 $\mathrm{mU} \mathrm{g}^{-1}$ fresh weight). In the cultivar studied, the PME activity ranged from 204.8 to $102.4\left(\mathrm{mU} \mathrm{g}^{-1}\right.$ fresh 

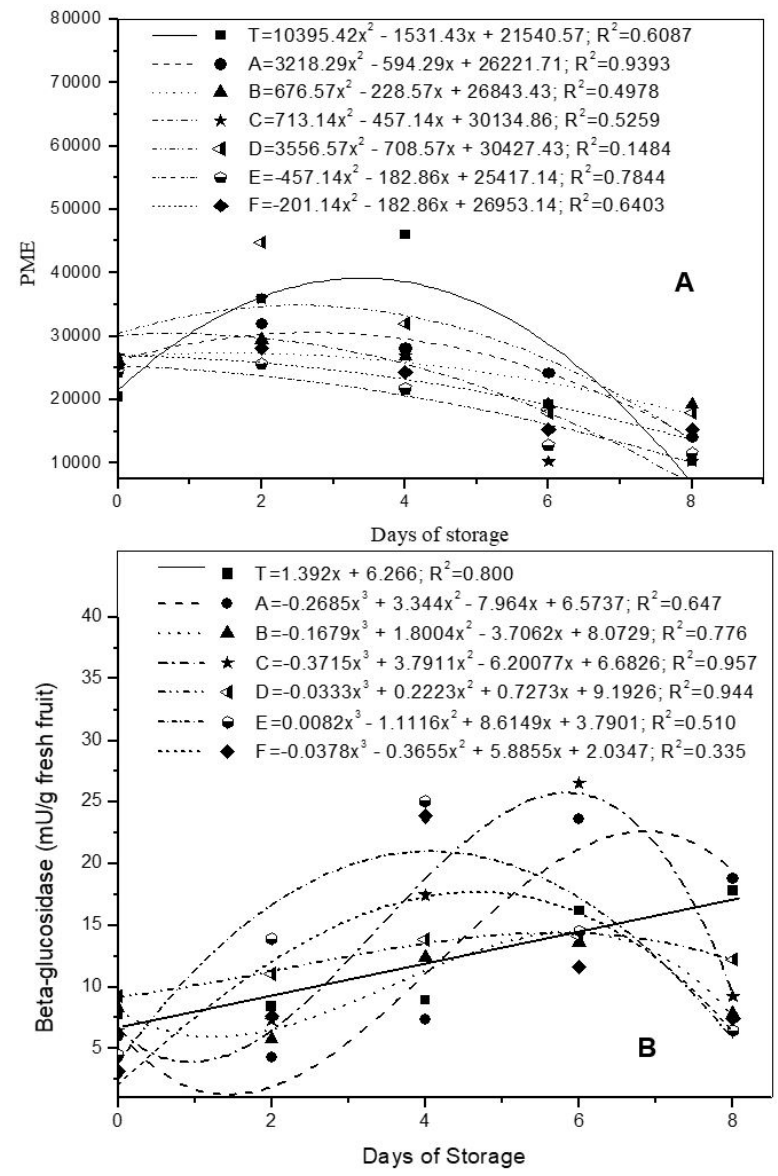

Figure 4. The effects of chitosan on the activities of pectin methylesterase and beta-glucosidase ( $\mathrm{mU} / \mathrm{g}$ fresh fruit) during storage. Groups: T (No coating); A (0.5\% Chitosan $132 \mathrm{kDa})$; B (1.5\% Chitosan $132 \mathrm{kDa}) ; \mathrm{C}(0.5 \%$ Chitosan $228 \mathrm{kDa})$; D (1.5\% Chitosan $228 \mathrm{kDa}) ; \mathrm{E}(0.5 \%$ Chitosan $245 \mathrm{kDa})$; and $\mathrm{F}$ $(1.5 \%$ Chitosan $245 \mathrm{kDa})$. The data were subjected to a regression analysis $(p<0.05)$.

weight), the value found in the control group at the end of storage. The control group showed a wide variation in the total pectin content from the seventh to the eighth days of storage. It can be seen in Figure $3 \mathrm{~B}$ that the soluble pectin contents were higher in the control group up to the seventh day of storage. This value can be justified by the advanced state of senescence shown by the control group fruits at the end of storage.

The $\beta$-D-glucosidase activity (Figure 4B) was determined in the supernatant and sediment fractions using the chromogenic substrate p-nitrophenyl- $\beta$-D-glucopyran oside. However, the sediment showed no enzyme activity. The fruits of the control group showed an increase in the activity of $\beta$-D-glucosidase in the supernatant, ranging from $7.76 \mathrm{mU} \mathrm{g}^{-1}$ fresh guava pulp on zero day to $17.8 \mathrm{mU} \mathrm{g}^{-1}$ fresh guava pulp on the eighth day of storage. The lowest $\beta$-D-glucosidase activity was observed in the fruits treated with $1.5 \%$ chitosan $245 \mathrm{kDa}$, ranging from $3.13 \mathrm{mU} \mathrm{g}^{-1}$ on the first day of storage to $7.46 \mathrm{mU} \mathrm{g}^{-1}$ on the last day of storage. The highest activities were observed in group $\mathrm{C}$ on the sixth day of storage $\left(26.53 \mathrm{mU} \mathrm{g}^{-1}\right)$, followed by group A (23.64 $\mathrm{mU} \mathrm{g}^{-1}$ ); on the same day, the control group showed an activity of $16.21 \mathrm{mU} \mathrm{g}^{-1}$.

The involvement of cell wall hydrolases in the loss of pulp firmness has been described in several fruits. Ketsa and Daengkanit (1999) observed an increase in pectin dissolution with the decrease in pear firmness. Some studies have shown a low $\beta$-glucosidase activity in the ripening of star fruit, mango and tomato (CHIN et al., 1999; ALI et al., 2004; KONOZY et al., 2012).

The preparation of the chitosan structures as dense or porous structures in the coating of fruits, exploits the polycationic nature of chitosan. The structures can be easily synthesized by drying or coagulating slightly acidified aqueous solutions, since chitosan is composed of protonable amino groups and becomes soluble in polar media (BEPPU et al., 1999). Chitosan 245 kDa has a higher molar mass and thus forms a greater number of crosslinks, producing thicker, more adherent solutions.

Fráguas et al. (2015) characterized the commercial samples of chitosan used in this study with a view to the subsequent application of these films in fruit coatings. The film produced from 1.5\% chitosan $245 \mathrm{kDa}$ was the thickest one $(6,8 \mu \mathrm{m})$ with total solids of $6.3 \mathrm{~g} \mathrm{~m}^{-2}$ and water vapour permeability of $175,3 \mathrm{~g}_{\text {day }}{ }^{-1} \mathrm{~m}^{-2}$. These characteristics resulted in the more efficient formation of a porous crystalline network, which retarded the gas exchange of the fruits, leading to a better response during the storage days.

\section{Conclusions}

All treatments used in this study were effective in extending the quality of guava (cv. Pedro Sato) stored at room temperature for eight days. The treatments with different chitosan concentrations extended the quality of the fruit to more than four days, the fruits with no treatment being unfit for consumption as from the fourth day of storage. The treatments were effective in maintaining the integrity of the cell wall of the fruit, thus extending its shelf life. The filmogenic and barrier properties of chitosan were proven by the reduction in the weight loss rate of the fruits coated with chitosan that contributed to maintenance of the firmness of the fruit pulp.

Chitosan $245 \mathrm{kDa}$ showed the best results for quality maintenance during 8 days of storage at a concentration of $1.5 \%$, being suitable for consumption.

\section{Acknowledgements}

The authors are grateful to the Fundação de Amparo à Pesquisa do Estado de Minas Gerais (FAPEMIG), Coordenação de Aperfeiçoamento de Pessoal 
de Nivel Superior (CAPES) and the Conselho Nacional de Desenvolvimento Científico e Tecnológico (CNPq), for the grants provided.

\section{References}

ABREU, J. R.; SANTOS, C. D.; ABREU, C. M. P.; CASTRO, E. M. Histochemistry and morphoanatomy study on guava fruit during ripening. Food Science and Technology, v. 32, n. 1, p. 179-186, 2012a. http://dx.doi.org/10.1590/S0101-20612012005000019.

ABREU, J. R.; SANTOS, C. D.; ABREU, C. M. P.; CORRÊA, A. D.; LIMA, L. C. O. Sugar fractionation and pectin content during the ripening of guava cv. Pedro Sato. Food Science and Technology, v. 32, n. 1, p. 156-162, 2012b. http://dx. doi.org/10.1590/S010120612012005000029.

AGRAWAL, A. A.; CONNER, K. J.; JOHNSON, T. J.; WALLSGROVE, $R$. Ecological genetics of an induced plant defense against herbivores: additive genetic variance and costs of phenotypic plasticity. Evolution, v. 56, n. 11, p. 2206-2213, 2002. http:// dx.doi.org/10.1111/j.0014-3820.2002.tb00145.x. PMid:12487351.

ALI, Z. M.; CHIN, L. H.; LAZAN, H. A comparative study on wall degrading enzymes, pectin modifications and softening during ripening of selected tropical fruit. Plant Science, v. 167, n. 2, p. 317-327, 2004. http://dx.doi.org/10.1016/j.plantsci.2004.03.030.

BEPPU, M. M.; ARRUDA, E. J.; SANTANA, C. C. Síntese e caracterização de estruturas densas e porosas de quitosana. Polímeros, v. 9, n. 4, p. 163-169, 1999. http://dx.doi.org/10.1590/ S0104-14281999000400027.

BITTER, T.; MUIR, H. M. A. A modified uronic acid carbazole reaction. Analytical Biochemistry, v. 4, n. 4, p. 330-334, 1962. http://dx.doi.org/10.1016/0003-2697(62)90095-7. PMid:13971270.

BOTELHO, L. N. S.; ROCHA, D. A.; BRAGA, M. A.; SILVA, A.; ABREU, C. M. P. Quality of guava cv. 'Pedro Sato' treated with cassava starch and cinnamon essential oil. Scientia Horticulturae, v. 209, p. 214-220, 2016. http://dx. doi.org/10.1016/j.scienta.2016.06.012.

CERQUEIRA, T. S.; JACOMINO, A. P.; SASAKI, F. F.; ALLEONI, A. C. C. Recobrimento de goiabas com filmes protéicos e de quitosana. Bragantia, v. 70, n. 1, p. 216-221, 2011. http://dx.doi. org/10.1590/S0006-87052011000100028.

CHEN, Y. C.; QIAN, Y.; CHEN, Q.; TAO, C.; LI, Y.; LI, Y. Evaluation of pesticide residues in fruits and vegetables from Xiamen, China. Food Control, v. 22, n. 7, p. 1114-1120, 2011. http:// dx.doi.org/10.1016/j.foodcont.2011.01.007.

CHIN, L. H.; ALI, Z. M.; LAZAN, H. Cell wall modifications, degrading enzymes and softening of carambola fruit during ripening. Journal of Experimental Botany, v. 50, n. 335, p. 767-775, 1999. http://dx.doi.org/10.1093/jxb/50.335.767.

CHITARRA, M. I. F.; CHITARRA, A. B. Pós-colheita de frutas e hortaliças: fisiologia e manejo. 2. ed. Lavras: UFLA, 2005. 785 p.
FORATO, L. A.; BRITTO, D.; RIZZO, J. S.; GASTALDI, T. A.; ASSIS, O. B. G. Effect of cashew gum-carboxymethylcellulose edible coating in extending the shelf-life of fresh and cut guavas. Food Packaging and Shelf Life, v. 5, p. 68-74, 2015. http://dx.doi. org/10.1016/j.fpsl.2015.06.001.

FRÁGUAS, R. M.; SIMÃO, A. A.; FARIA, P. V.; QUEIROZ, E. R.; OLIVEIRA JUNIOR, Ê. N.; ABREU, C. M. P. Preparo e caracterização de filmes comestíveis de quitosana. Polímeros, v. 25, n. spe, p. 48-53, 2015. http://dx.doi.org/10.1590/0104-1428.1656.

GUERRA-SÁNCHEZ, M. G.; VEGA-PÉREZ, J.; VELÁZQUEZ-DEL VALLE, M. G.; HERNÁNDEZ-LAUZARDO, A. N. Antifungal activity and release of compounds on Rhizopus stolonifer (Ehrenb.:Fr.) Vuill. by effect of chitosan with different molecular weights. Pesticide Biochemistry and Physiology, v. 93, n. 1, p. 18-22, 2009. http://dx. doi.org/10.1016/j.pestbp.2008.09.001.

JANUÁRIAVIEIRA, S. M.; RAGA, A.; BENEDETTI, B. C.; OLIVEIRA, R. A.; MARCO, P. G. D.; SCARPONI, A. P. T. Effect of ultraviolet-C radiation on "Kumagai" guavas infested by Ceratitiscapitata (Diptera-Tephritidae) and on physical parameters of postharvest. Scientia Horticulturae, v. 165, p. 295-302, 2014. http://dx.doi. org/10.1016/j.scienta.2013.11.015.

JEN, J. J.; ROBINSON, M. L. P. Pectolytic enzymes in sweet bell peppers (Capsicum annuum L.). Journal of Food Science, v. 49, n. 4, p. 1085-1087, 1984. http://dx.doi.org/10.1111/j.1365-2621.1984. tb10398.x.

KETSA, S.; DAENGKANIT, T. Firmness and activities of polygalacturonase, pectinesterase, b-galactosidase and cellulase in ripening durian harvested at different stages of maturity. Scientia Horticulturae, v. 80 , n. 3-4, p. 181-188, 1999. http:// dx.doi.org/10.1016/S0304-4238(98)00242-8.

KONOZY, E. H. E.; CAUSSE, M.; FAUROBERT, M. Cell wall glycosidase activities and protein contente variations during fruit development and ripening in three texture contrasted tomato cultivars. Saudi Journal of Biological Sciences, v. 19, n. 3 , p. 277-283, 2012. http://dx.doi.org/10.1016/j.sjbs.2012.04.006. PMid:23961187.

LINHARES, L. A.; SANTOS, C. D.; ABREU, C. M. P.; CORREAA, A. D. Chemical, physical and enzymatic transformations of guavas 'Pedro Sato' treated at postharvest with calcium chlorite and 1-methylciclopropone and stored under refrigeration. Ciência e Agrotecnologia, v. 31, n. 3, p. 829-841, 2007. http://dx.doi. org/10.1590/\$1413-70542007000300033.

LIU, F. H.; CHEN, F.; YANG, H.; YAO, Y.; GONG, X.; XIN, Y.; DING, C. Effect of calcium treatment on nanostructure of chelate-soluble pectin and physicochemical and textural properties of apricot fruits. Food Research International, v. 42, n. 8, p. 1131-1140, 2009. http://dx.doi.org/10.1016/j.foodres.2009.05.014.

MANICA, I.; ICUMA, I. M.; JUNQUEIRA, N. T. V.; SALVADOR, J. O.; MOREIRA, A.; MALAVOLTA, E. Goiaba. Porto Alegre: Cinco Continetntes, 2000. 374 p. 
MCCREADY, R. M.; MCCOOMB, E. A. Extraction and determination of total pectic materials in fruits. Analytical Chemistry, v. 24, n. 12, p. 1986-1988, 1952. http://dx.doi.org/10.1021/ac60072a033.

OLIVEIRA JUNIOR, E. N.; SANTOS, C. D.; ABREU, C. M. P.; CORRÊA, A. D.; SANTOS, J. Z. L. Postharvest changes of "fruta-de-lobo" (Solanum lycocarpum St. Hil.) during the ripening process: physical-chemical, chemical and enzymatic analysis. Revista Brasileira de Fruticultura, v. 26, n. 3, p. 410-413, 2004.

Oliveira, A. C. G.; ZANÃO, C. F. P.; ANICETO, A. P. P.; SPOTO, M. H. F.; CANNIATTI-BRAZACA, S. G.; WALDER, J. M. M. Conservação pós-colheita de goiaba branca Kumagai por irradiação gama: aspectos físicos, químicos e sensoriais. Boletim CEPPA, v. 24, n. 2, p. 375-396, 2006.

PEREIRA, L. M.; RODRIGUES, A. C. C.; SARANTÓPOULOS, C. I. G. L.; JUNQUEIRA, V. C. A.; CARDELLO, H. M. A. B.; HUBINGER, M. D. Vida de prateleira de goiabas minimamente processadas acondicionadas em embalagens com atmosfera modificada. Food Science and Technology, v. 23, n. 3, p. 427-433, 2003. http://dx.doi.org/10.1590/S0101-20612003000300023.

PINTO, P. M.; JACOMINO, A. P.; CAVALINI, F. C.; CUNHA-JUNIOR, L. C.; INOUE, K. N. Maturity stages of Kumagai and Pedro
Sato"guava fruits for fresh cut. Ciência Rural, v. 40, n. 1, p. 37-43, 2010. http://dx.doi.org/10.1590/S0103-84782009005000244.

RIBEIRO, V. G.; ASSIS, J. S.; SILVA, F. F.; SIQUEIRA, P. P. X.; VILARONGA, C. P. P. Armazenamento de goiabas 'Paluma' sob refrigeração e em condição ambiente, com e sem tratamento com cera de Carnaúba. Revista Brasileira de Fruticultura, v. 27, n. 2, p. 203-206, 2005. http://dx.doi.org/10.1590/S010029452005000200005.

VILAS BOAS, B. M.; ALVES, A. P.; ALVES, J. A.; RODRIGUES, L. J.; ALVES, T. C.; VILAS BOAS, E. V. B. Physical, chemical and biochemical characterization of pequi fruit harvested at different stages of development. Ciência Rural, v. 43, n. 12, p. 2285-2290, 2013.

XISTO, A. L. R. P.; ABREU, C. M. P.; CORRÊA, A. D.; SANTOS, C. $D$. Texture of "Pedro Sato" guavas submitted to the application of calcium cloride. Ciência e Agrotecnologia, v. 28, n. 1, p. 113-118, 2004. http://dx.doi.org/10.1590/S1413-70542004000100015.

YOSHIDA, C. M. P.; OLIVEIRA JUNIOR, E. N.; FRANCO, T. T. Chitosan tailor-made films: the effects of additives on barrier and mechanical properties. Packaging Technology \& Science, v. 22, n. 3, p. 161-170, 2008. http://dx.doi.org/10.1002/pts.839. 